\title{
Drying of residual tilapia skin from filleting using a thermophotovoltaic solar dehydrator
}

\author{
Secagem da pele de tilápia residual de filetagem em desidratador solar termofotovoltaico \\ Karina dos Santos Rodrigues ${ }^{1}$ (D), Eveny Silva de Melo ${ }^{1 *}$ (1), Isabel Cristina da Paz Lima ${ }^{3}$ (D), \\ Rafael Gomes Abreu Bacelar ${ }^{4}$ (1), Alexandre Miranda Pires dos Anjos 5 (D), Maria Christina Sanches Muratorib (D), \\ Maria Marlucia Gomes Pereira Nobregab (i)
}

\begin{abstract}
Tilapia comprises one of the most cultivated fish species worldwide, mainly commercialized in the form of fillets. As a result, the amount of waste generated by processing is high, with tilapia skin being commonly discarded and not used as food for human consumption. In this context, the aim of this study was to dry residual filleted tilapia skins in a solar dehydrator and perform physical-chemical analyses after drying in order to evaluate the potential for the development of byproducts. The skins were collected at a fish market on Mercado do Peixe in Teresina - PI. Treatments consisted of four sodium chloride concentrations $(0.0 \% ; 25.0 \% ; 50.0 \%$ and $100.0 \%)$, with five replications, totaling 25 samples. The skins were dried in the solar dehydrator for 24 hours, followed by moisture, ash, protein, lipids, $\mathrm{pH}$ and water activity analyses. Moisture in the in natura skins was $57.7 \%$, differing significantly from the dehydrated tilapia skins, which ranged from $9.4 \%$ to $10.6 \%$. The ash in the in natura skins was $0.17 \%$, while dehydrated tilapia skins displayed variations from $1.19 \%$ to $4.17 \%$. The crude protein found of the in natura skins was $41.4 \%$, significantly different $(\mathrm{P}<0.05)$ from the skins submitted to the solar dehydration method. Based on these findings, the use of solar dehydrator for short periods is confirmed to favor the uniform dehydration of residual tilapia skin from filleting, generating a product with satisfactory bromatological patterns for the development of fish-based by-products.
\end{abstract}

KEYWORDS: Oreochromis sp. Reuse. Solid waste. Solar dehydrator.

\begin{abstract}
RESUMO: A tilápia é uma das espécies de peixe mais cultivadas no mundo, sendo comercializada principalmente na forma de filé, com isso, a quantidade de resíduos gerada com o processamento é elevada, sendo a pele de tilápia comumente descartada e não aproveitada como alimento de consumo humano. Desta forma, o objetivo desse estudo foi aproveitar peles de tilápia residuais de filetagem e realizar análises físico-química após secagem em desidratador solar afim de avaliar seu potencial para desenvolvimento de coprodutos. As peles foram coletadas no Mercado do Peixe em Teresina - PI. Foram definidos os tratamentos, adicionando quatro concentraçôes de cloreto de sódio $(0,0 \% ; 25,0 \% ; 50,0 \%$ e 100,0\%), com cinco repetições, totalizando 25 amostras. As peles foram encaminhadas para secagem no desidratador solar por 24 horas. Depois, realizou-se as análises de umidade, cinzas, proteína, lipídios, $\mathrm{pH}$ e atividade de água. O teor de umidade encontrado na pele em natureza foi de 57,7\%, diferindo significativamente das peles de tilápia desidratadas que variaram de $9,4 \%$ a $10,6 \%$. O teor de cinzas encontrado na pele em natureza foi de $0,17 \%$, enquanto nas peles de tilápia desidratadas houve uma variaçáo de $1,19 \%$ a $4,17 \%$. A proteína bruta encontrada nas peles da tilápia em natureza foi de $41,4 \%$, diferindo significativamente $(\mathrm{P}<0,05)$ das peles submetidas ao método de desidratação solar. Com base nos resultados observados nesse estudo, conclui-se que a utilização de desidratador solar em curtos períodos favorece a desidratação uniforme da pele de tilápia residual de filetagem, gerando produto com padrôes bromatológicos satisfatórios para o desenvolvimento de coprodutos à base de pescado.
\end{abstract}

PALAVRAS-CHAVE: Oreochromis sp. Reaproveitamento. Resíduo sólido. Desidratador solar.

\section{INTRODUCTION}

Modern society has increasingly demonstrated greater concerns for health and the environment, especially due to the negative environmental impact that industrial activities can cause. In this context, the food industry has sought to supply consumer desires for healthier, fresher, palatable products, microbiologically safe and free of additives, investing in innovative "clean" technologies, which maintain desirable food

\footnotetext{
${ }^{1}$ Médica Veterinária, Especialista em Tecnologia e Inspeção de Produtos de Origem Animal pelo Programa de Residência Multiprofissional em Saúde da Universidade Federal do Piauí, Teresina, Brasil

3Médica Veterinária, Universidade Federal do Piauí, Teresina, Brasil

"Médico Veterinário, Doutorando do Programa de Pós-graduação em Ciência Animal da Universidade Federal do Piauí, Teresina, Brasil

${ }^{5}$ Físico, Docente do Departamento de Física, Universidade Federal do Piauí, Teresina, Brasil

`Médica Veterinária, Docente do Departamento de Morfofisiologia Veterinária, Universidade Federal do Piauí, Teresina, Brasil.

*Corresponding author: evenymelo06@hotmail.com

Received: 10/19/2020. Accepted: 01/31/2021
} 
characteristics without harming the environment (TOEPFL et al., 2006; PIRES et al., 2014).

In 2019, Nile tilapia production represented $57 \%$ of all Brazilian fish farming, of great importance for the country's economic and food sectors (BRASIL, 2020). Processing companies generate significant amounts of waste with tilapia processing, comprising about $70 \%$ of the volume processed, which is not always used (LEONEL, 2016). Fish waste includes all leftovers from processing, such as head, bones, skin and viscera, among others, which contain high protein, mineral and lipids contents (STEVANATO et al., 2007; SILVA et al., 2009). The environmental and economic sustainability of this production chain depends on the use of this generated waste.

Fish skin represents an average of $7.5 \%$ of the total fish weight (FRANCO, 2013; YOSHIDA et al., 2016), and can be used to produce leather and gelatine. However, due to its high sensitivity to bacterial and autolytic degradation, fish skin must be correctly stored and distributed in order to preserve its quality. To this end, both cold or dehydration can be applied to inhibit microbial development (SOUZA, 2004; BORDIGNON et al., 2012; EUGÊNIO, 2018).

Dehydration can be accomplished through forced air circulation using heat, generated by wood and oil pyrolysis and electrical energy. The use of non-polluting renewable sources to generate energy has become an ecologically viable alternative for this process, especially in regions with favorable environmental conditions. Different types of solar dryers are available, and indirect exposure dryers display the advantage of protecting food against direct sun exposure, resulting in better quality products (NASCIMENTO et al., 2015).

Solar energy applied in food dehydration displays several sustainable characteristics, such as being renewable, releasing no waste into the atmosphere and displaying great potential, in addition to being widely available in almost all of Brazil, especially in the Northeast (MACHADO; MIRANDA, 2015).

Considering the relevance of the waste generated by fish filleting that can be transformed into fish-based byproducts, with consequent decreases of environmental impacts, alternative ways to use this raw material for human consumption are required. In this context, the aim of this study was to dry residual filleted tilapia skins in a solar dehydrator and perform physical-chemical analyses after drying in order to evaluate the potential for the development of fish-based byproducts.

\section{MATERIAL AND METHODS}

\section{Tilapia skin sampling}

The samples were acquired directly from fish market traders on Mercado do Peixe in Teresina - PI that fillet tilapia (Oreochromis sp.) and discard the skins after processing. The samples were packed in plastic bags and transported in isothermal boxes containing recyclable ice to the Fish Technology Laboratory.

\section{Sample preparation}

At the Fish Technology laboratory, the scales were removed from the skins with the aid of a manual metal extractor and discarded. The skins were then washed under running water, cut into $5.0 \mathrm{~cm} \times 3.0 \mathrm{~cm}$ pieces and, finally, immersed in hyperchlorinated water containing $5.0 \mathrm{ppm}$ of free residual chlorine for 10 minutes.

\section{Salting and dehydration}

After preparing the skins, the salting and drying treatments were defined as follows: control group (in natura, without sodium chloride addition and without undergoing the dehydration process) and four sodium chloride treatments $(0.0 \% ; 25.0 \% ; 50.0 \%$ and $100.0 \%)$ followed by the dehydration process, comprising five repetitions, totaling 25 samples.

Direct sodium chloride addition was performed uniformly on the surface of each sample. The skins were then placed on drying trays in an indirect exposure Ecodrytec 216GII Thermo-photovoltaic Solar Dehydrator, where the air is heated in the collector and being blown into the chamber where dehydration by natural convection or with the aid of a fan is performed for 24 hours. The control group samples were immediately analyzed at the PhysicalChemical Food Control Laboratory. After drying, the samples from the sodium chloride treatments were sent to the laboratory for analysis.

\section{Solar dehydration}

The solar dehydrator used to dry the samples (Figure 2) displays an internal capacity of 216 liters and measured $200 \times 180 \times 700 \mathrm{~cm}$, built in sheet metal, consisting of eight stainless steel shelves, totaling a useful area of about $3.0 \mathrm{~m}^{2}$.

The device does not require electricity or gas to function and works under clear to partially cloudy sky condition. No integrated system for measuring and recording temperature

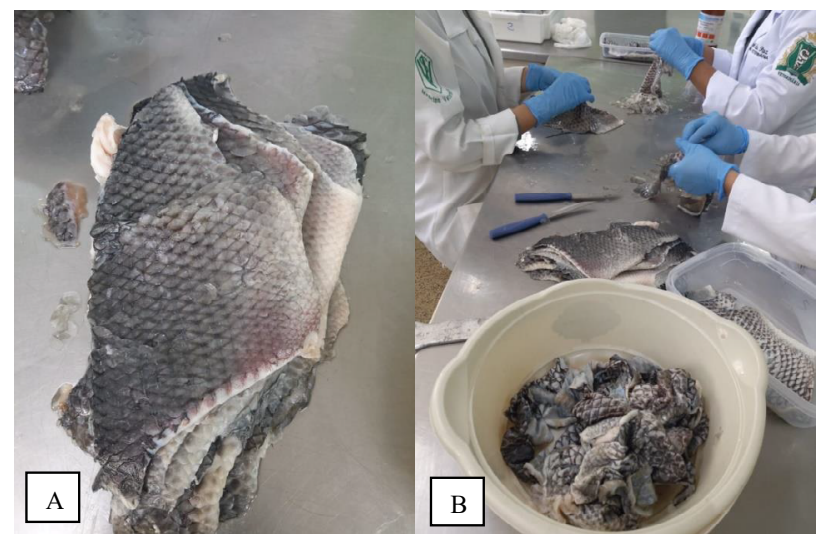

Source: Personal archive (2019).

Figure 1. Tilapia skins collected at Mercado do Peixe in Teresina PI (A) Removal of scales for sample preparation (B). 


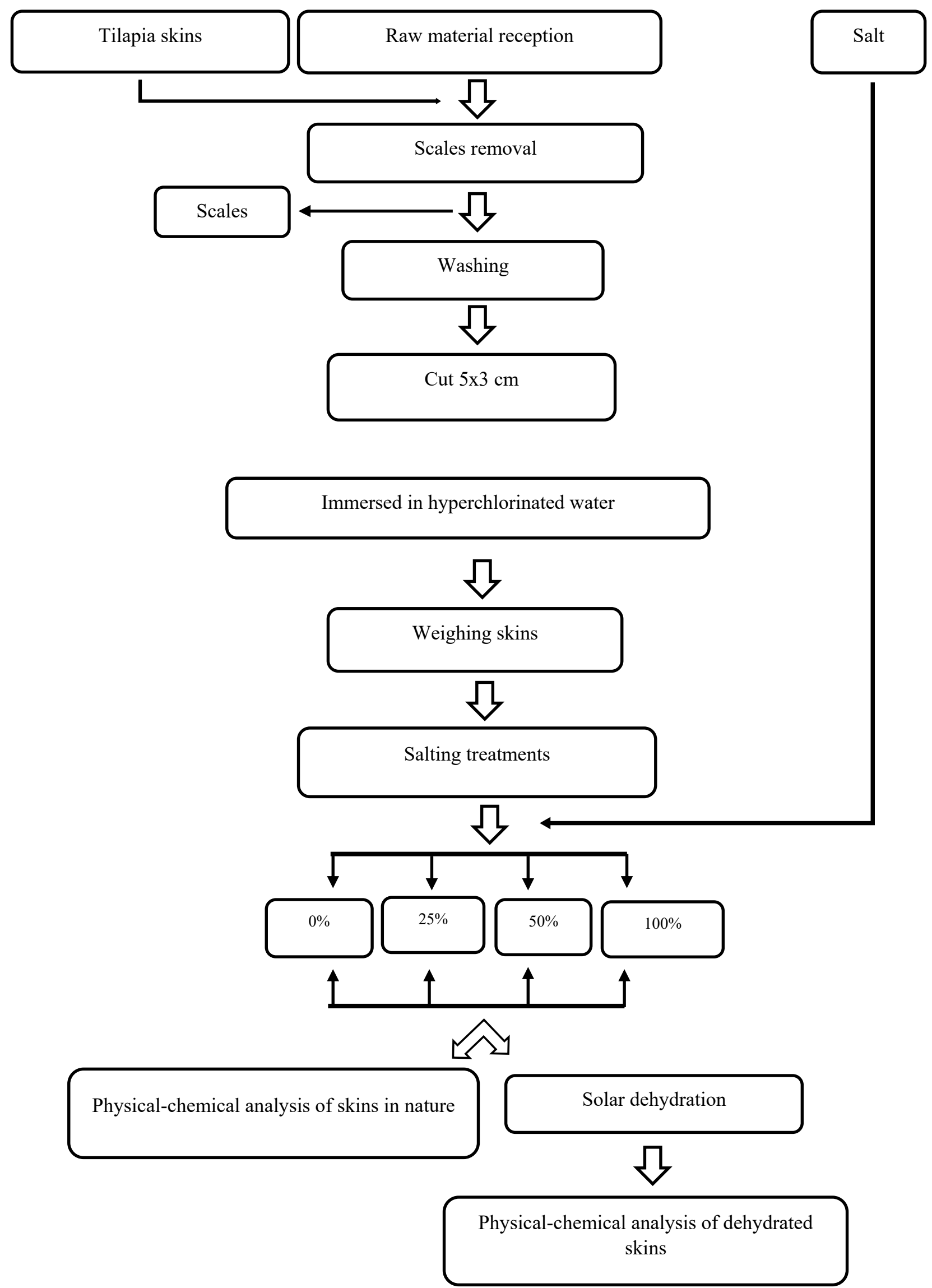

Figure 2. Flowchart demonstrating the process of dehydrating the tilapia skin 
parameters or relative humidity is available. The operating temperature range varies from $40{ }^{\circ} \mathrm{C}$ to $80^{\circ} \mathrm{C}$ and the forced ventilation is controlled with an analog flow control system by a potentiometer.

Dehydration took place in September 2019. The samples were placed in the solar dehydrator in the morning, at around 9:00 am, and removed the next day, at the same time, totaling 24 hours in the solar dehydrator.

The climatic conditions of the municipality of Teresina-PI (latitude-5.2403, longitude-42.67914) in September 2019 were obtained directly from the Climatempo site, which provides climatological forecasts, as follows: minimum temperature of $22^{\circ} \mathrm{C}$, maximum temperature of $36^{\circ} \mathrm{C}$ and $9.0 \mathrm{~mm}$ precipitation (Figure 3) (CLIMATEMPO, 2019).

\section{Physicochemical analyses}

The following physicochemical analyses were carried out at the Núcleo de Estudos Pesquisas e Processamento de Alimentos (NUEPPA), Physical-Chemical Food Control Laboratory: moisture content, ash, protein, lipids, $\mathrm{pH}$ and water activity. All analyses were performed in triplicate.

\section{Moisture content determinations}

Tilapia skin moisture content was determined by the method based on weight loss after heating and water removal (AOAC, 2016). This method consists of direct heating of a $2.0 \mathrm{~g}$ sample in a porcelain capsule in an oven at $105^{\circ} \mathrm{C}$ for three hours, until reaching constant weight. The samples were subsequently placed in the desiccator for cooling and weighed for the calculations to be performed.

\section{Ash determinations}

Ash contents were determined by the incineration method, consisted of carbonizing and incinerating a $2.0 \mathrm{~g}$ sample in a muffle furnace at $550^{\circ} \mathrm{C}$ for four hours, in a previously tared porcelain capsule, until complete coal removal. This results in a white or slightly gray ash, which is then placed in a desiccator to cool for one hour, and weighed for the calculations to be performed (AOAC, 2016).

\section{Protein determinations}

Protein determinations was performed using the micro-Kjeldahl method. With the aid of an analytical balance, approximately $0.25 \mathrm{~g}$ of each sample were weighed and transferred to a tube, followed by the addition of $2.5 \mathrm{~g}$ of a catalytic mixture and 7.0 $\mathrm{mL}$ of sulfuric acid and heating in a digestion block until obtaining a clear and transparent liquid, with a blue-green tint, characterizing the sample digestion. In this method, organic nitrogen is transformed into ammonia and organic components are converted into $\mathrm{CO}_{2}$ and $\mathrm{H}_{2} \mathrm{O}$. This is followed by distillation out, which consists of collecting the ammonia gas released in the receiving solution (boric acid) and, finally, titration, when the quantitative determination of the ammonia contained in the receiving solution (boric acid) is carried out (AOAC, 2016).

\section{Lipid determinations}

The amount of lipids present in the tilapia skin samples was determined by the Soxhlet method, where $2.0 \mathrm{~g}$ of each sample were weighed, packed in filter paper and taken to the extractor. The extraction process took place over six hours, using petroleum ether as solvent (AOAC, 2016).
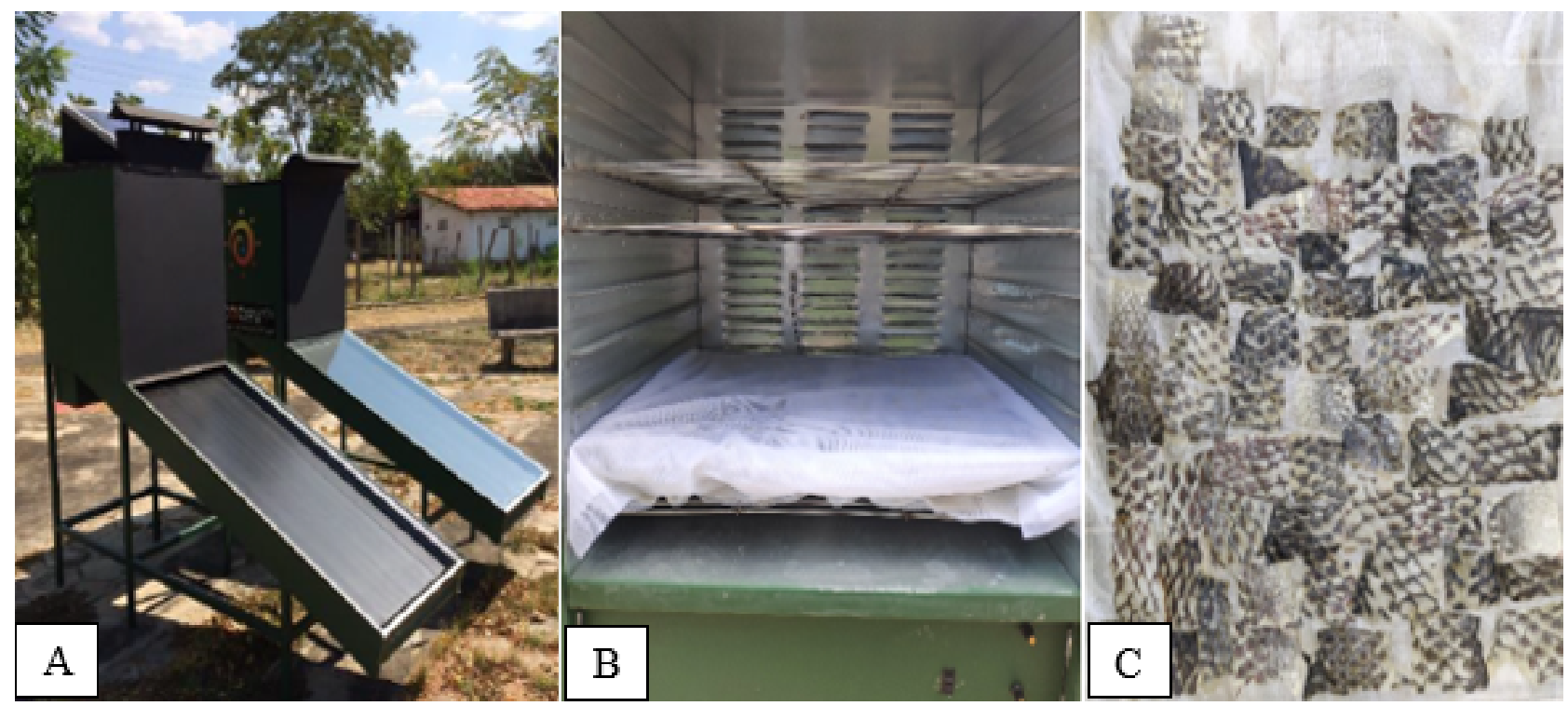

Source: Personal archive (2019).

Figure 3. Solar dehydrator Photovoltaic term Ecodrytec (A) Distribution of samples in the dehydrator (B) and samples after dehydration process (C). 


\section{pH determinations}

The $\mathrm{pH}$ analyses were performed with the aid of a bench MPA210 MS Tecnopon Instrumentação pHmeter. Briefly, $10 \mathrm{~g}$ of each sample were weighed and placed in a beaker-type flask containing $100 \mathrm{~mL}$ of distilled water. The electrode was then introduced in the middle and the results were obtained after reading stabilization (AOAC, 2016).

\section{Aw determinations}

The water activity (Aw) analyses were performed using a portable Decagon Devices Pawkit sensor. Briefly, 3.0g of each sample were placed in a plastic container attached to the sensor, and the result was obtained directly from the device.

\section{Statistical analyses}

An Analysis of variance (ANOVA) was performed, applying the Holm-Sidak test to compare the variable means, adopting a significance level of $\mathrm{P}=<0.001$, using the Sigmastat 4.0 software.

\section{RESULTS AND DISCUSSION}

The average room temperature during the experiment was of $36^{\circ} \mathrm{C}$. With this, the solar dehydrator performance reached up to $80^{\circ} \mathrm{C}$ with hot air circulation. According to Celestino (2010), the ability to eliminate water from a food item depends, mainly, on temperature and relative air humidity. Table 1 presents the results of the centesimal tilapia skin composition analysis for the in natura (control) samples and those submitted to solar dehydration following different sodium chloride treatments.

The moisture content of the in natura skins (control) was $57.7 \%$, significantly different from the dehydrated tilapia skin content, which ranged from $9.4 \%$ to $10.6 \%$. The different washing and preserving methods prior to processing may also influence tilapia skin moisture content, especially concerning the drying time after the process. The differences observed between the in natura and dehydrated skins are due to the dehydration process, that causes moisture and mass losses. About $100 \mathrm{~g}$ of each skin sample was used for each treatment, decreasing to $35 \mathrm{~g}$ after the dehydration process.

The ash content of the in natura skins was $0.17 \%$, while the dehydrated tilapia skins exhibited variations from $1.19 \%$ to $4.17 \%$. The ash content increased gradually in the sodium chloride treated dehydrated skins. Bordignon et al. (2012) reported an ash content for frozen tilapia skins of $1.44 \%$ and for slated skins of $2.06 \%$, similar to the values observed herein. This difference is probably due to differences between the two sodium chloride addition methods.

The Nile tilapia skins were not significantly different concerning lipid content between treatments $(\mathrm{P}=<0.001)$, with averages

\section{Teresina - PI}

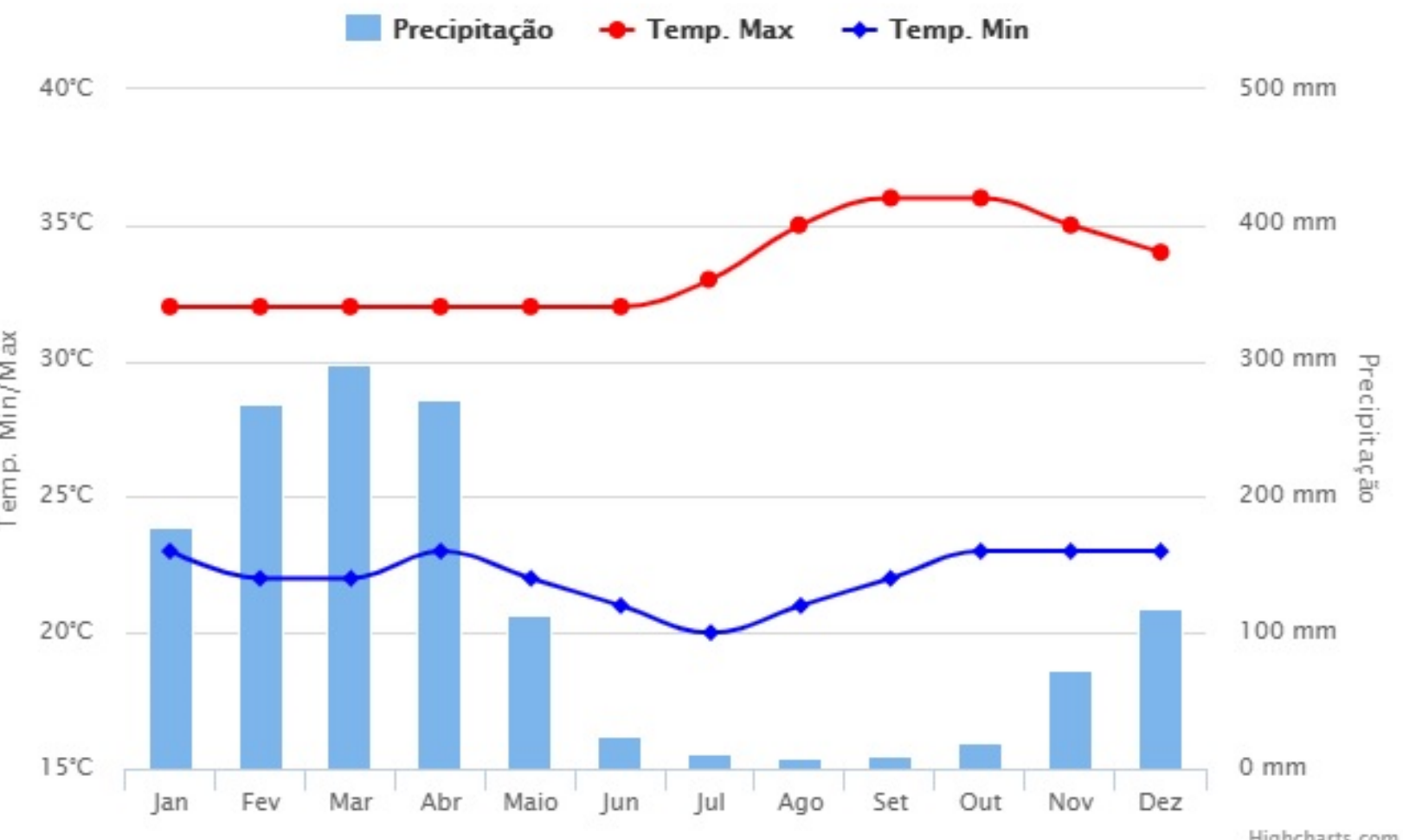


Table 1. Average and standard deviation of the results of physical-chemical analyzes of samples of tilapia (Oreochromis sp.) Skins in nature and dehydrated with different percentages of sodium chloride.

\begin{tabular}{l|c|c|c|c|c}
\multirow{2}{*}{ Parameters analyzed } & Skin in nature & \multicolumn{4}{|c}{ Dehydrated skin (Treatments with sodium chloride\%) } \\
\cline { 2 - 6 } & (Control) & $0 \%$ & $25 \%$ & $50 \%$ & $100 \%$ \\
\hline Moisture (\%) & $57.7^{\mathrm{a}} \pm 4.1$ & $10.0^{\mathrm{b}} \pm 1.6$ & $9.4^{\mathrm{b}} \pm 1.9$ & $9.8^{\mathrm{b}} \pm 2.2$ & $10.6^{\mathrm{b}} \pm 1.8$ \\
\hline Ash (\%) & $0.2^{\mathrm{c}} \pm 0.03$ & $1.2^{\mathrm{b}} \pm 1.16$ & $2.0^{\mathrm{b}} \pm 0.49$ & $2.5^{\mathrm{b}} \pm 0.85$ & $4.2^{\mathrm{a}} \pm 1.0$ \\
\hline Lipids (\%) & $10.4^{\mathrm{a}} \pm 2.9$ & $13.0^{\mathrm{a}} \pm 3.5$ & $15.3^{\mathrm{a}} \pm 4.1$ & $14.3^{\mathrm{a}} \pm 1.9$ & $13.7^{\mathrm{a}} \pm 5.1$ \\
\hline Protein (\%) & $41.4^{\mathrm{b}} \pm 1.2$ & $81.9^{\mathrm{a}} \pm 10.4$ & $84.7^{\mathrm{a}} \pm 4.0$ & $78.5^{\mathrm{ab}} \pm 8.3$ & $75.0^{\mathrm{ab}} \pm 6.2$ \\
\hline $\mathrm{pH}$ & $6.7^{\mathrm{a}} \pm 0.18$ & $6.9^{\mathrm{a}} \pm 0.53$ & $6.6^{\mathrm{a}} \pm 0.56$ & $6.6^{\mathrm{a}} \pm 0.62$ & $6.7^{\mathrm{a}} \pm 0.72$ \\
\hline Aw & $0.8^{\mathrm{a}} \pm 0.00$ & $0.4^{\mathrm{b}} \pm 0.07$ & $0.4^{\mathrm{b}} \pm 0.08$ & $0.4^{\mathrm{b}} \pm 0.08$ & $0.4^{\mathrm{b}} \pm 0.08$ \\
\hline
\end{tabular}

Means on the same line followed by different letters differ from each other by the Holm-Sidak test $(P=<0.001)$. Data expressed as mean \pm standard deviation.

ranging from $10.4 \%$ to $15.3 \%$. The lipid content of the in natura skins were the lowest, while the lipid contents of the skins submitted to the solar dehydration method were higher. The dehydration process probably resulted in nutrient sample concentration. Bordignon et al. (2012) reported lipid values between $19.0 \mathrm{~g} \mathrm{~kg}-1$ $(1.90 \%)$ and $22.6 \mathrm{~g} \mathrm{~kg}^{-1}(2.26 \%)$, higher than those observed in the present study, for frozen and salted Nile tilapia skins.

The crude protein content of the in natura skins (control) was $41.4 \%$, differing significantly $(\mathrm{P}=<0.001)$ from skins submitted to the solar dehydration method, which presented higher and similar values. Ferreira et al. (2015) reported crude protein values of $18.2 \%$ and $19.6 \%$ in Nile tilapia skins preserved by freezing and dry salting, in contrast to Bueno et al. (2011), who reported protein tilapia skin gelatin values of $89.4 \%$ and $88.9 \%$. These variations may be due to dehydration, that tends to concentrate nutrients due to water removal.

No significant differences between treatments were observed for $\mathrm{pH}$, with averages ranging from 6.68 to 6.94 . As samples were in accordance with the Brazilian legislation, which recommends a fish meat $\mathrm{pH}$ of less than 7.00 (BRASIL, 2017).

The water activity values of the in natura skins was 0.86 , differing significantly from dehydrated tilapia skins, which ranged from 0.39 to 0.40 . These differences are due to the dehydration process, that results in water loss. The sodium chloride concentrations did not affect tilapia skin moisture contents or water activity (Table 1). Therefore, dehydration was influenced only by the use of the solar desiccator.

According to Souza Filho, et al., (2012), microorganisms generally grow on substrates displaying water activity between 0.90 and 0.99 , while yeasts and mycelial fungi usually grow in water activity ranging from 0.86 to 0.88 , and some filamentous fungi are able to grow in water activity of up to 0.80 . Therefore, the water activity of the dehydrated tilapia skins indicates adequate stability, inhibiting microbiological multiplication and increasing conservation periods.

\section{CONCLUSION}

The use of the solar dehydrator for short periods of time favors the uniform dehydration of residual filleting tilapia skins, generating a product displaying satisfactory bromatological standards. Therefore, we conclude that this type of waste displays potential for the development of fish-based byproducts, depending on the processing technique. This is, thus, a viable alternative from an economic and environmental point of view, applying a renewable and clean technology.

\section{REFERENCES}

AOAC International. Official Methods of Analysis of AOAC International, Official Method 965.26. 20ed. Rockville: 2016.

BORDIGNON, A.C. et al. Aproveitamento de peles de tilápia-donilo congeladas e salgadas para extração de gelatina em processo batelada. Revista Brasileira de Zootecnia.v. 41, n. 3, p. 473-478, 2012.

BRASIL. Regulamento da Inspeção Industrial e Sanitária de Produtos de Origem Animal (RIISPOA). Disponível em: < https:/ www.gov.br/agricultura/pt-br/assuntos/inspecao/produtos-animal/ arquivos/decreto-n-9013-2017_alt-decreto-9069-2017_pt.pdf/ view> Acesso em: 20 jan. 2020.
Associação Brasileira de Pesca e Aquicultura. Anuário Brasileiro da Piscicultura. São Paulo: PEIXE BR, 2020. 136 p. Disponível em: https:/www.peixebr.com.br/anuario-2020/. Acesso em: 23 nov. 2020.

BUENO, C.M. et al. Produção de gelatina de pele de tilápia e sua utilização para obtenção de micropartículas contendo óleo de salmão. Brazilian Journal of Food Technology, Campinas, v. 14, ก. 1, p. 65-73, 2011.

CELESTINO, S.M.C. Princípios de secagem de alimentos. Planaltina: Embrapa cerrados, p. 10, 2010. 
CLIMATEMPO. Médias climatológicas da cidade de Teresina em 2019. Disponível em: <https:/www.climatempo.com.br/ climatologia/264/teresina-pi> Acesso em: 08 jan.2020.

EUGÊNIO, D. A. Desenvolvimento e avaliação de desempenho de um desidratador híbrido solar de produtos agro alimentícios. 2018 27f. Monografia (Trabalho de Conclusão do Curso em Engenharia de Energia) - Escola de Engenharia, Universidade Federal do Rio Grande do Sul, Porto Alegre, 2018.

FERREIRA, M.C.M.; GOMES, A.F.; GOZZO, A.M. Extração e caracterização de gelatina a partir de subprodutos de tilápia do nilo (Sarotherodon niloticus), p. 1786-1792. In: Anais: XI CONGRESSO BRASILEIRODEENCENHARIAQUÍMICAEMINICIAÇÃOCIENTÍFICA. São Paulo. v. 1, n.3. 2015.

FRANCO M.L.R.S. et al. Comparação das peles de tilápia do Nilo, pacu e tambaqui: Histologia, composição e resistência. Arch Zootec, vol.62(237), p.2l-32, 2013.

LEONEL, A. P. S. Viabilidade econômica de produtos á base de tilápia para alimentação escolar nos municípios de Toledo-PR e Marechal Cândido Rondon-PR. 2016. 87 p. Tese (Doutorado em Aquicultura) - Universidade Estadual Paulista, Centro de Aquicultura, Jaboticabal.

MACHADO, C.T.; MIRANDA, F.S. Energia Solar Fotovoltaica: Uma Breve Revisão. Revista Virtual de Química, vol. 7, n. 1, p.l26143,2015

NASCIMENTO, A.L.A. et al. Desenvolvimento de Desidratador Solar de Alimentos com Sistema de Aquisição de Dados em Plataforma Arduino. Caderno de Ciências Agrárias, vol. 7, p. 29-34, 2015.
PIRES, D. R. et al. Aproveitamento do resíduo comestível do pescado: Aplicação e viabilidade. Revista Verde de Agroecologia e Desenvolvimento Sustentável, vol. 9, p. 34-46, 2014.

SILVA, F.V.E. et al. Características morfométricas, rendimentos de carcaça, filé, vísceras e resíduos em tilápias-do-nilo em diferentes faixas de peso. Revista Brasileira de Zootecnia / Brazilian Journal of Animal Science, vol. 38, p. 1407/1806-9290, 2009.

SILVA, G.C.O. et al. Obtenção e caracterização físico-química e microbiológica da gelatina de resíduos de matrinxã (Brycon amazonicus) e tambaqui (Colossoma macroponum). ACTAPESCA, vol. 6, p. 74-84, 2018

SOUZAFILHO, M.S.M. et al. Obtenção e caracterização de gelatina de pele de tilápia. Embrapa Agroindústria tropical. 19p. 2012.

SOUZA, M.L.R. Tecnologia para processamento das peles de peixe. Coleção Fundamentum, vol.ll, p.59. Maringá: Eduem, 2004.

STEVANATO, F. B. et al. Avaliação química e sensorial da farinha de resíduo de tilápias na forma de sopa. Food Science and Technology, vol.27, p.567-571, 2007.

TOEPFL, S. et al. Review: Potential of High Hydrostatic Pressure and Pulsed Electric Fields forEnergy Efficient and Environmentally Friendly Food Processing. Food Reviews International, vol.22, p.405-423, 2006.

VIDAL, J.M.A. et al. Concentrado protéico de resíduos da filetagem de tilápia-do-nilo (Oreochromis niloticus): caracterização físico-química e aceitaçãosensorial. RevistaCiênciaAgronômica, vol.42, no.l, p.92-99,2011.

YOSHIDA, G. M.et al. Análises mecânicas efísico-químicas de couros de tilápia, cacharae salmão.Archivos deZootecnia, vol.65, p.349-355,2016. 